\title{
Total Lipodystrophy
}

\author{
ANGELA FAIRNEY, GEORGE LEWIS, and DENNIS COTTOM \\ From The Hostital for Sick Children, London; and St. Mary's Hospital, Portsmouth
}

Lipodystrophy is a little understood disorder of subcutaneous tissue. It may occur in two forms, partial or total. In partial lipodystrophy there is progressive wasting of subcutaneous tissue of the face, trunks, or limbs. Poley and Stickler (1963) were able to collect data on 50 cases of this type seen at the Mayo Clinic. They noted that growth, sexual development, and reproductive ability were not influenced by the lipodystrophy. Subsequently, Senior and Gellis (1964) found a significant incidence of renal disease in cases of partial lipodystrophy. This is an entirely different condition from the much rarer congenital generalized lipodystrophy, of which only some 20 cases have been reported. These infants are noted to be abnormal at birth, and have an increased rate of growth, together with hepatosplenomegaly, cardiomegaly, skin pigmentation, and hypertrichosis. Previous authors on this subject (Berardinelli, 1954; Seip and Trygstad, 1963; Senior and Gellis, 1964; Choremis, Constantinides, and Kattamis, 1965) have suggested that there is a disturbance of the hypothalamic-hypophysial system in this condition.

We here report a case of congenital generalized lipodystrophy, with serum insulin and growth hormone level determinations.

\section{Case Report}

A 6-month-old male child (Fig. 1 and 2) was referred for diagnosis as the parents were worried about lack of subcutaneous fat on the arms, legs, and buttocks. He also had an unusual facial appearance and abdominal distension. His developmental progress had been normal. He appeared lively, played normally, had a good appetite, and did not seem to have any defect of vision or hearing. Past history revealed that he was born at full term after a normal pregnancy and labour. His birthweight was $2.76 \mathrm{~kg}$. and he was bottle-fed on a full-cream dried milk from birth. His neonatal period was uneventful. He smiled at 6 weeks, had head control at 1-2 months, and sat supported at the age of 6 months. There was no relevant family history. He has one normal male sib aged 2 years.

Examination showed that he was a happy, playful, large child with an unusual elfin-like facies. He was

Received November 25, 1968. on the 40th centile for weight and above the 95th centile for height. There was no clinically detectable subcutaneous fat, and no skeletal deformity. His knee and elbow joints seemed lax and his anterior fontanelle was open. His face was hirsute, with a low hairline. There was no pubic or axillary hair. His abdomen was distended and he had large, well-developed external genitalia. The liver was soft and palpable $3 \mathrm{~cm}$. below the right costal margin. There was no splenomegaly. There was accentuation of the pulmonary component of the second heart sound, with a soft, mid-systolic murmur down the left sternal edge. His blood pressure was $140 / 90 \mathrm{~mm} . \mathrm{Hg}$, and he had normal peripheral pulses. The fundi were normal. His hands and feet were large and his limbs generally hypotonic. He followed a light well, had good head control, and took an alert interest in his surroundings.

Investigations. Blood. $\mathrm{Hb} 11 \cdot 1$ g., PCV $35 \%$, MCHC $32 \%$, WBC 9100/cu.mm., platelets 244,000/ cu.mm.

Plasma. Na $139 \mathrm{mEq} / \mathrm{l} ., \mathrm{K} \quad 4.6 \mathrm{mEq} / 1 ., \mathrm{TCO}_{2}$ $20 \mathrm{mEq} / \mathrm{l}$., urea $19 \mathrm{mg} . / 100 \mathrm{ml}$. Fasting plasma $\mathrm{Ca}$ $10.4 \mathrm{mg} . / 100 \mathrm{ml}$. (normal 8.5-10.5 mg.); fasting plasma phosphorus $5 \cdot 7 \mathrm{mg} . / 100 \mathrm{ml}$. (normal 4.0-5.5); cholesterol $139 \mathrm{mg} . / 100 \mathrm{ml}$. (normal 100-220); PBI $3 \cdot 7 \mu \mathrm{g} . / 100 \mathrm{ml}$. (normal 3.3-7·4).

Liver function tests. Serum total proteins $6 \cdot 8 \mathrm{~g}$. with a raised $a_{2}$-globulin on electrophoretic strip. SGOT $141 \mu$ moles, SGPT $170 \mu$ moles $/ \mathrm{hr}$. per $100 \mathrm{ml}$. (normal 10-110). Total bilirubin $<0.7 \mathrm{mg} . / 100 \mathrm{ml}$. Plasma alkaline phosphatase $25 \mathrm{KA}$ units $/ 100 \mathrm{ml}$. (normal 10-22).

Urine. No protein or cells. 24-hour urineamino acid chromatogram normal. 17-ketosteroids $0.2 \mathrm{mg}$. (normal $0.25 \mathrm{mg}$. $\pm 0.12 \mathrm{mg}$.). Total 17hydroxycorticoids $1 \cdot 2 \mathrm{mg}$. (normal $1 \cdot 0-4 \cdot 5 \mathrm{mg}$.).

Urine sugars. Lactose $<5 \mathrm{mg} . / 100 \mathrm{ml}$, galactose $5 \mathrm{mg} . / 100 \mathrm{ml}$., glucose $5 \mathrm{mg} . / 100 \mathrm{ml}$., sucrose $5 \mathrm{mg}$./ $100 \mathrm{ml}$., fructose $20 \mathrm{mg} . / 100 \mathrm{ml}$.

Results of a glucose tolerance test are set out in Table I. Fasting serum insulins: $9,11,8 \mu \mathrm{U} / \mathrm{ml}$. on 3 separate days. Serum creatine phosphokinase $2 \cdot 4 \mu$ moles/ ml. per hr. (normal 0-3-4.5). Fasting blood lipids: total lipids $475 \mathrm{mg} . / 100 \mathrm{ml}$. Paper electrophoresis showed some pre- $\beta$-lipoprotein; $a$-lipoprotein was reduced.

Growth hormone levels (HGH ng./100 ml.). 1 hour after glucose $2 \cdot 8$; short fast $1 \cdot 0$; long fast $26 \cdot 8$ (normal results). 


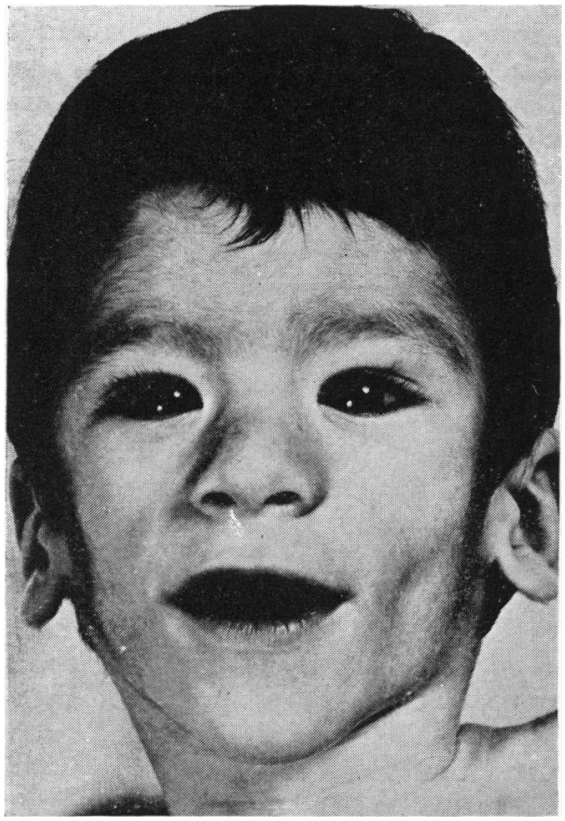

Fig. 1.-Facial appearance showing lack of subcutaneous tissue and hirsutism.

Bovril stimulation test (HGH ng./100 ml.). Fasting $9 \cdot 05$; $30 \mathrm{~min} .12 \cdot 8$; $60 \mathrm{~min} .12 \cdot 7 ; 90 \mathrm{~min} .15 \cdot 3$; $120 \mathrm{~min} .14 \cdot 0 ; 150 \mathrm{~min} .17 \cdot 6$ (normal results).

$X$-rays. Chest showed congenital abnormalities of the 5th and 6th right ribs. Wrist showed that the centres were not developing in their usual order. Bone age at 6 months was 9 months (Fig. 3). Skull was of unusual shape, flattened posteriorly, and in the frontal region. There was no intracranial calcification. Intravenous pyelogram showed good excretion of the medium, but the pelvicalycine systems had a slightly odd appearance (Fig. 4) (see under Discussion).

$E C G$ showed LV hypertrophy.

$E E G$, normal.

Histology of skin biopsy. Epidermis, dermal appendages, and the superficial dermis normal. There was no normal subcutaneous adipose layer, it being replaced by acellular fibrous tissue in which there were numerous well-demarcated islands of adipose tissue. These were abnormal in that the majority of the cells were not vacuolated with lipid, while the collagenous stroma was prominent.

\section{Discussion}

In 1946 Lawrence described a patient with lipodystrophy associated with hepatomegaly, diabetes, and hyperlipaemia, and drew attention to accounts of 2 patients with similar findings which had been described earlier (Ziegler, 1928; Hansen and McQuarrie, 1940). Since that time, some 21 cases have been described (Table II), and the

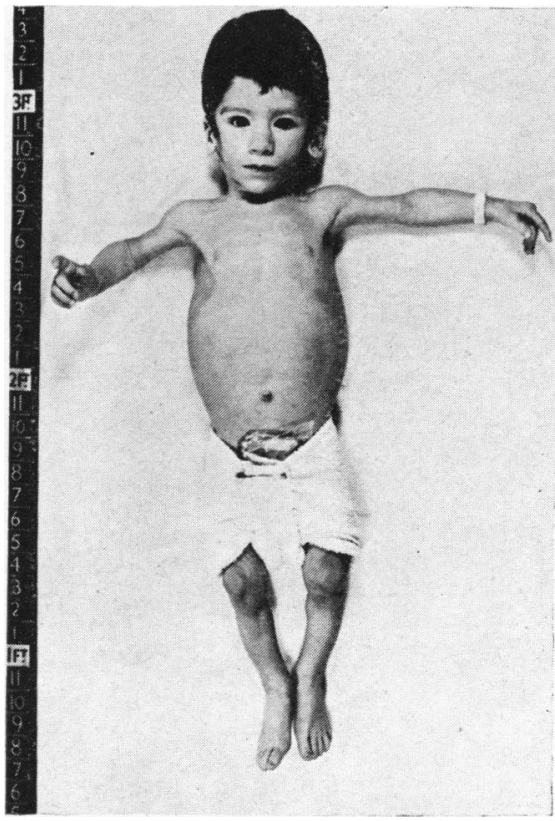

Fig. 2.-Patient at 6 months, showing lack of subcutaneous tissue associated with abdominal distension due to hepatomegaly.

main features of the syndrome are lipodystrophy and hepatomegaly, associated with accelerated growth, hirsuties, pigmentation, abdominal protruberance, and enlargement of the genitalia. The relative lack of fat gives the appearance of muscular hypertrophy. In addition, hyperglycaemia, hyperlipaemia, an increased metabolic rate, cardiomegaly, nephropathy, and abnormalities of the central nervous systems are frequent findings.

The disorder was obvious at birth in our case as in 7 of the reported cases, but in others loss of adipose tissue occurred during childhood. The generalized absence of fat was confirmed by marrow aspiration (Witzgall, 1957; Schwartz, Schafer, and Renold, 1960), and at laparotomy in the cases reported by Corner (1952) and Senior (1961).

TABLE I

Giucose Tolerance Test

\begin{tabular}{c|c|c}
\hline $\begin{array}{c}\text { Time } \\
(\mathrm{hr} .)\end{array}$ & $\begin{array}{c}\text { Blood Sugar } \\
(\mathrm{mg} . / 100 \mathrm{ml} .)\end{array}$ & $\begin{array}{c}\text { Serum Insulin } \\
(\mu \mathrm{U} / \mathrm{ml} .)\end{array}$ \\
\hline 0 & 83 & 26 \\
$\frac{1}{2}$ & 83 & 9 \\
1 & 100 & 14 \\
$1 \frac{1}{2}$ & 97 & 13 \\
2 & 89 & 7 \\
\hline
\end{tabular}




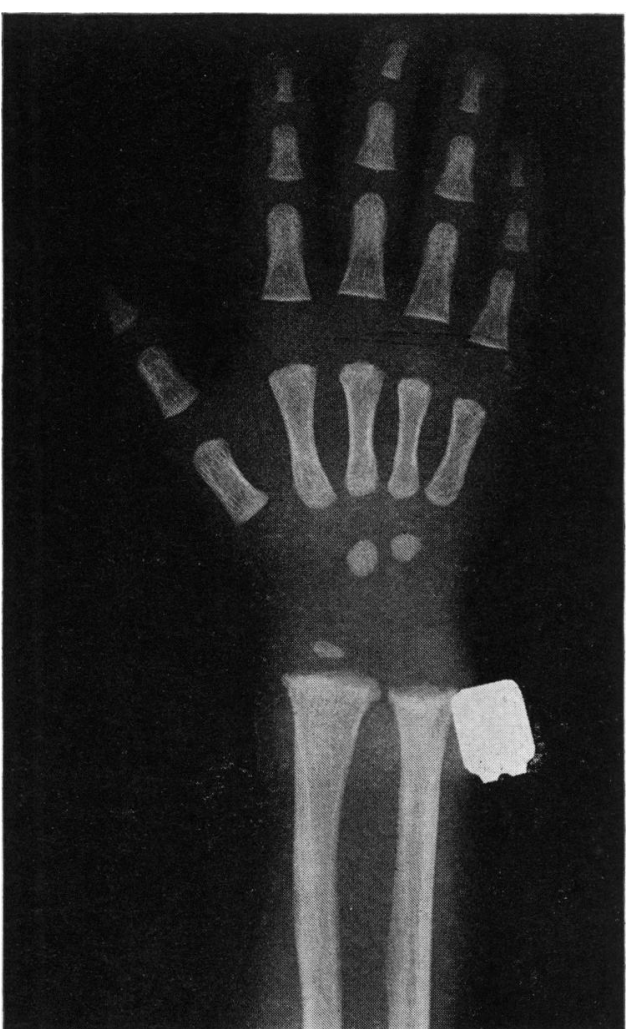

FIG. 3.-X-ray of wrist at 6 months showing advanced bone age of 9 months.
Marked hepatomegaly was a constant finding, and where histology was available it showed round cell infiltration with deposition of fat and glycogen. Gastro-intestinal bleeding was the cause of death in 4 patients, and in 2 who came to necropsy there was advanced cirrhosis. Already at the age of 6 months our patient has abnormally high serum transaminases and raised $a_{2}$-globulin.

Penile or clitoral hypertrophy was apparent in 11 patients, as in our case; again there were no other signs of sexual precocity apart from the increased growth rate and the muscular appearance. Equally the 17-ketosteroids and 17-ketogenic steroids fell within the normal range, as did the case reported by Ruvalcaba, Samols, and Kelley (1965), though Seip and Trygstad (1963) found these to be slightly increased.

The presence of abnormal pigmentation was a feature of 16 of a total of 26 case reports, and recently Reed et al. (1965) have described the occurrence of acanthosis nigricans in a patient with total lipodystrophy. As yet there is no exceptional pigmentation in our case.

Renal anomalies are more common in partial lipodystrophy, and in the series reviewed by Senior and Gellis (1964), 14 of 77 patients had a variety of disorders, including glomerulonephritis, hydronephrosis, and pyelonephritis. Nephromegaly has been noted on a number of occasions, and was present in our case. His kidneys were $8 \mathrm{~cm}$. in length compared with normal for his age of $6 \mathrm{~cm}$. or $6.6 \mathrm{~cm}$. for a child of his height (Hodson

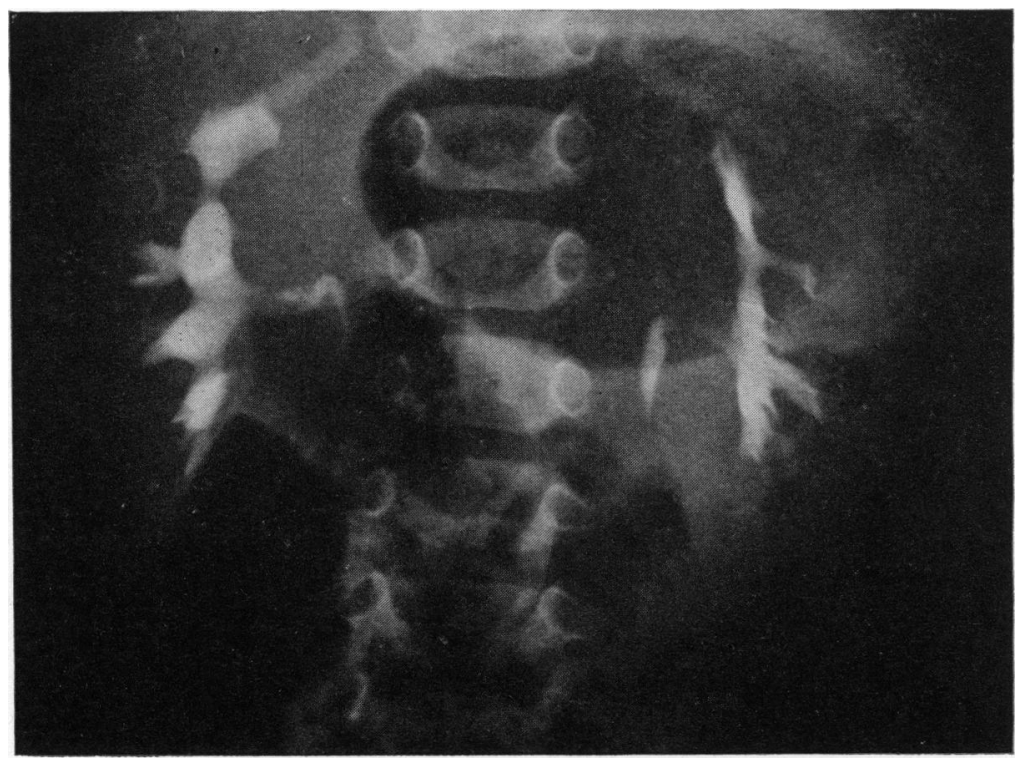

Fig. 4.-Pyelogram showing unusual pelvicalycine pattern. 
TABLE II

Generalized Lipodystrophy

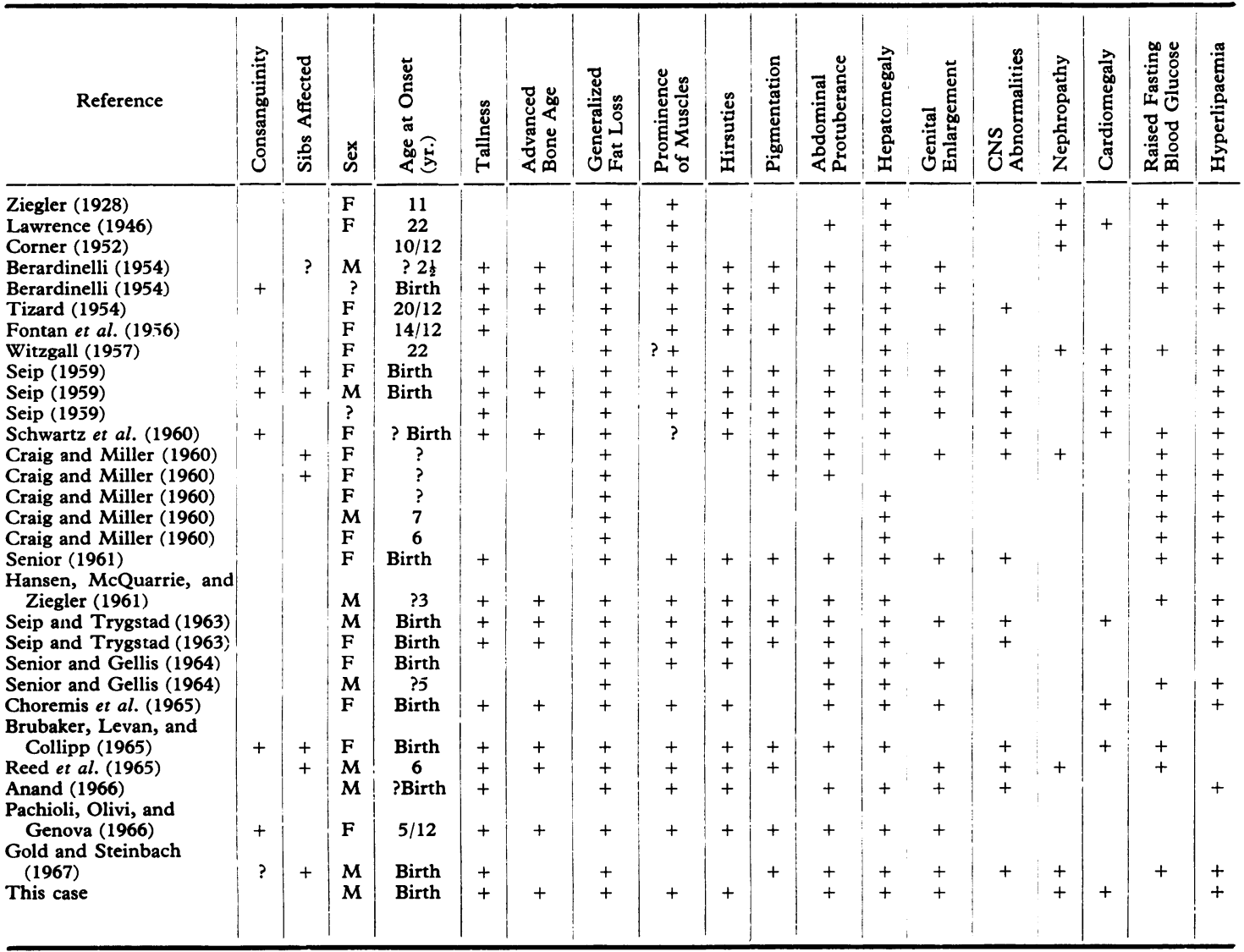

et al., 1962). There was no proteinuria, the blood urea was normal, and there was no evidence of tubular dysfunction; on the other hand, the pyelogram showed an unusual arrangement of the pelvicalycine systems (Fig. 4).

Numerous hypotheses have attempted to explain the lack of fat in adipose tissue. Basically it might be due to an intrinsic disorder of the cell or to some agent, hormonal or otherwise, which prevents the accumulation of fat within the cell. Skin biopsy yielded little information; as in Lawrence's (1946) original patient, the specimens obtained from our case showed complete absence of fat in subcutaneous tissue. The appearances could be interpreted as indicating that the adipose tissue was still in an embryonic state and incapable of storing fat, or that fat transport was abnormal so it was immediately mobilized from normal cells. Langhof and Zabel (1960) performed an auto- transplant in a patient with a partial lipodystrophy. They found that fatty tissue implanted into an atrophic site lost fat while atrophic tissue put into a normal area tended to gain fat. This suggests that it is the local environment rather than the cell itself which is at fault, but this may not apply in the rather different total lipodystrophy.

It is conceivable that the inability of the cells to store fat might result in hyperglycaemia, high circulating lipids, and excessive fat deposition in the liver. If the basic lesion is the inability of the cells to incorporate fat, it is difficult to explain the genital hypertrophy, pigmentation, hirsuties, and advanced bone age. Though local cellular factors may predominate in partial lipodystrophy, it is probable that a humoral agent is responsible for the over-all clinical picture in total lipodystrophy. Seip and Trygstad (1963) have suggested that there is an underlying hypothalamic disorder, and in 
some of their patients an abnormal ventriculogram seems to support this hypothesis. In addition, they found high levels of growth hormone (HGH) in 3 out of 5 of their patients, though equally their 2 patients with normal HGH had clinical evidence of increased growth (Read and Stone, 1958). They used Read's haemagglutination inhibition method to estimate $\mathrm{HGH}$, and it is well known that this tends to give higher values than a radio-immunoassay technique.

In our patient $\mathrm{HGH}$, when measured by a modification of the double antibody method described by Morgan and Lazarow (1963), fell within the normal range. Similarly, when investigated at the age of 6 months and again at 1 year, the serum insulin levels were normal. It seems likely that the clinical syndrome of total lipodystrophy can be fully established before detectable changes in HGH and serum insulin appear.

\section{Summary}

A patient with generalized lipodystrophy which was apparent at birth is reported. He showed hepatomegaly, increased growth, and an advanced bone age, together with hirsutism and large external genitalia. Contrary to previous suggestions that the syndrome results from hyperfunction of the anterior pituitary, normal levels for serum insulin and growth hormone were obtained.

We are grateful to Dr. David Grant for the estimations of serum insulin, to Dr. Barbara Clayton for much helpful advice, to Mr. S. Lunnon of the Department of Medical Illustration for the photographs, and to Miss Patricia Filby for secretarial assistance.

\section{REFERENCES}

Anand, J. S. (1966). Lipodystrophic muscular hypertrophy with arthrogryposis multiplex congenita. Indian $\mathcal{F}$. Pediat., 33, 152.

Berardinelli, W. (1954). An undiagnosed endocrinometabolic syndrome: report of two cases. F. clin. Endocr., 14, 193.

Brubaker, M. M., Levan, N. E., and Collipp, P. J. (1965). Acanthosis nigricans and congenital total lipodystrophy. Arch. Derm., 91, 320.

Choremis, K. B., Constantinides, B., and Kattamis, C. A. (1965). Congenital type of generalized lipodystrophy. Acta paediat. scand., 54, 175.

Corner, B. D. (1952). Lipoatrophic diabetes. In British Paediatric Association. Proceedings of the twenty-third general meeting. Arch. Dis. Childh., 27, 300.
Craig, J. W., and Miller, M. (1960). Lipoatrcp'xic diabetes. In Diabetes, p. 700. Ed. by R. H. Williams. Hoeber, New York.

Fontan, A. Z., Verger, P., Couteau, J. M., and Péry, M. (1956). Hypertrophie musculaire généralisée à début précoce, avec lipodystrophie faciale hépatomégalie et hypertrophie clitoridienne chez une fille de 11 ans. Arch. franc. Pediat., 13, 276.

Gold, R. H., and Steinbach, H. L. (1967). Lipoatrophic diabetes mellitus (generalized lipodystrophy): roentgen findings in two brothers with congenital disease. Amer. F. Roentgen., $101,884$.

Hansen, A. E., and McQuarrie, I. (1940). Serum and tissue lipids in a peculiar type of generalized lipodystrophy. Amer. F. Dis. Child., 60, 754.

$\longrightarrow$, - and Ziegler, M. R. (1961). Lipohistiodiaresis: a syndrome of lipodystrophy universalis, accelerated growth, lipemia, hepatic cirrhosis, and insulin-resistant diabetes without ketosis. f.-Lancet, 81, 533.

Hodson, C. J., Drewe, J. A., Karn, M. N., and King, A. (1962). Renal size in normal children. A radiographic study during life. Arch. Dis. Childh., 37, 616.

Langhof, H., and Zabel, R. (1963). Zur Lizodystrophia progressiva. Arch. klin. exp. Derm., 210, 313.

Lawrence, R. D. (1946). Lipodystrophy and hepatomegaly with diabetes, lipaemia, and other metabolic disturbances. A case throwing new light on the action of insulin. Lancet, 1, 724 and 773.

Morgan, C. R., and Lazarow, A. (1963). Immunoassay of insulin: two antibody system. Diabetes, 12,115 .

Pachioli, R., Olivi, O., and Genova, R. (1966). La lipodistrophia, un qua:lro di paniperpituitarismo anteriore nell' infanzia. Mineria pediat., 18, 1387.

Poley, J. R., and Stickler, G. B. (1963). Progressive lipodystrophy. Amer. F. Dis. Child., 106, 356.

Read, C. H., and Stone, D. B. (1958). An immunologic assay for minute amounts of human pituitary growth hormone. ibid., 96, 538.

Reed, W. B., Dexter, R., Corley, C., and Fish, C. (1965). Congenital lipodystrophic diabetes with acanthosis nigricans. Arch. Derm., 91, 326.

Ruvalcaba, R. H. A., Samo!s, E., and Kelley, V. C. (1965). I.ipoatrophic diabetes. Amer. F. I is. Clild., 109, 279.

Schwartz, R., Schafer, I. A., and Renold, A. E. (1960). Generalized lipoatrophy, hepatic cirrhosis, disturbed carbohydrate metabolism and accelerated growth (lipoatrophic diabetes): longitudinal observations and metabolic studies. Amer. F. Med., 28, 973.

Seip, M (1959). Lipodystrophy and gigantism with associated endocrine manifestations: a new diencephalic syndrome? Acta paediat. (L'ppsala), 48, 555.

- and Trygstad, O. (1963). Generalized lipodystrophy. Arch. Dis. Childh., 38, 447.

Senior, B. (1961). Lipodystrophic muscular hypertrophy. Arch. Dis. Childh., 36, 426.

_, and Gellis, S. S. (1964). The syndromes of total lipodystrophy and of partial lipodystrophy. Pediatrics, 33, 593 .

Tizard, J. P. M. (1954). Generalized lipodystrophy. Infectious mononucleosis. Mild infantile hemiplegia. Proc. roy. Soc. Med., 47, 128.

Witzgall, H. (1957). Hyperlipämische Lipoatrophie. Arztl. Wchschr., 12, 1093.

Ziegler, L. H. (1928). Lipodystrophies: report of 7 cases. Brain, $51,147$.

Correspondence to Dr. Dennis Cottom, The Hospital for Sick Children, Great Ormond Street, London W.C.1. 